\title{
OSMOPHORE DIVERSITY IN THE CATASETUM CRISTATUM ALLIANCE (ORCHIDACEAE: CATASETINAE)
}

\author{
Evelyn P. Franken ${ }^{1,2}$, Ludmila M. Pansarin ${ }^{1} \&$ Emerson R. Pansarin $^{1}$ \\ ${ }^{1}$ Biology Department, Faculty of Philosophy, Sciences and Literature of Ribeirão Preto/University of \\ São Paulo - FFCLRP/USP. Av. Bandeirantes, 3900. CEP 14040-901. Ribeirão Preto/SP. Brazil. \\ ${ }^{2}$ Author for correspondence: efranken@usp.br
}

\begin{abstract}
AвSTRACt. Catasetum is a neotropical orchid genus of 130 species characterized by its unisexual flowers. They are pollinated by male Euglossini bees. It is widely know that these bees collect volatile compounds in Catasetum from structures called osmophores. However, there is little information on morpho-anatomy and histochemistry of secretory tissues for this neotropical genus and data are lacking. Based on these arguments members of the Catasetum cristatum alliance, namely C. arietinum, C. ariquemense, C. barbatum, C. carolinianum, C. cristatum, C. lanciferum, C. multifidum, C. multifissum, C. rivularium and C. semicirculatum were analyzed. The labellum of male flowers of this alliance is elongate and with fimbriate margins, possessing two protuberances and a median saccate portion. The labellum of female flowers is galeiform and there is no ornamentation. The entire adaxial surface of the labellum is secretory in both sexes, including the fimbriae of male flowers. The structure of the secretory tissue is similar among species, and they are composed of a simple epidermis and five layers of underlying parenchyma. In most species the epidermis is flat, and cells are elongated in the saccate portion. In C. ariquemense and C. carolinianum the epidermal cells are papillous, while in C. semicirculatum they have convex surface (male flowers). The histochemical analysis detected lipophilic droplets and starch grains inside the secretory cells. All characteristics observed are encountered in secretory tissues with high-energy demand, as is common in osmophores.
\end{abstract}

KEY WORDS: Euglossini bees, floral glands, flower reward, pollination, volatile compounds

Introduction. Nectar is the most common and widespread floral reward among orchids (e.g., van der Pijl \& Dodson 1966). However, a significant number of species reward their pollinators (i.e., male euglossine bees) with volatile compounds. These volatile oils are produced in structures called osmophores (Vogel 1990). In Orchidaceae, two types of osmophores have been reported, namely glandular and epidermal (e. g., Effmert et al. 2006). Osmophores are commonly formed by a single layer of epidermal cells, with unior multicellular papillae, or several layers of cells. According to Vogel (1990), osmophores cells have big nuclei, dense cytoplasm, large amount of starch and high number of mitochondria and other organelles. The majority of these characteristics can be found in tissues with high metabolic activity, which is related to the secretion process (Fahn 2000). Studies about osmophores anatomic structure has been conducted in a number of unrelated orchid genera, such as in Restrepia (Pridgeon \& Stern 1983), Scaphosepalum (Pridgeon \& Stern 1985), Stanhopea (Stern et al. 1987, Curry et al. 1988, Curry et al. 1991, Pansarin \& Amaral
2009, Anton et al. 2012), Sievekingia (Curry et al. 1991), Kegeliella (Curry \& Stern 1991), Cymbidium (Stpiczynska 1993), Gymnadenia (Stpiczynska 2001), Bulbophyllum (Teixeira et al. 2004, Nunes et al. 2014, 2015, Kowalkowska et al. 2015), Ophrys (Ascensão et al. 2005, Francisco \& Ascensão 2013), Cyrtopodium (Pansarin et al. 2008), Cyclopogon (Wiemer et al. 2009), Grobya (Pansarin et al. 2009), Acianthera (de Melo et al. 2010), Cycnoches (Anton et al. 2012), Chlorea (Sanguinetti et al. 2012), Vanilla (Pansarin et al. 2014), Cirrhaea (Pansarin et al. 2014), Gongora (Adachi et al. 2015) and Catasetum (Vogel 1963).

Catasetum Rich. (Orchidaceae) has approximately 130 species distributed mainly through the tropical region of Central and South America (Romero et al. 2009). The majority of the species occur in the Brazilian Amazon, where this genus is well represented (Miranda \& Lacerda 1992). The species are indistinguishable based on the morphology of their vegetative structures. The flowers are usually unisexual and, occasionally hermaphrodite (with no reproductive function). All three flower shapes (staminate, pistillate and hermaphrodite) 
have distinct morphology and may occur in the same individual and sometimes in the same inflorescence (Romero \& Nelson 1986, Romero 1992, Gerlach 2013). Within Catasetum some species alliances are recognized based on the morphology of male flowers and particularly on the relative position of the staminodes (Bicalho \& Barros 1988). The "C. cristatum alliance" belongs to the subsection Isoceras, which has parallel or symmetrical antennae (i.e., staminodes). The species of this group exhibits a strong morphological similarity and new information are required for taxa delimitation (Lacerda 1998).

For more than fifty years is known that Catasetum species are pollinated by male Euglossini bees (Hymenoptera, Apidae), which collect volatile compounds at the flowers (Vogel 1963). In this case, the fragrance compounds are volatilized and act as an attractant and a resource for male euglossine bees that collect them with a hard hair structure present on their anterior legs and are stored into the hind tibiae (Eltz et al. 1999). These fragrances consist mainly on a variety of terpenoids and aromatics that sometimes possess a species-specific composition (Hills et al. 1972, Gerlach \& Schill 1991). During fragrance collection, bees incidentally contact the antennae of staminate (male) flowers and the pollinarium is deposited on the bee's body (mainly on the scutum). When visiting a pistillate (female) flower, the pollinia deposition in the stigmatic cleft can occur (Dodson 1962, Dressler 1968). Flower morphology and osmophore disposition on the labellum may guide the pollinator for a correct position to the pollinarium adherence and deposition (e.g., Dressler 1993).

Since the work of Vogel (1963), none further information about flower anatomy of Catasetum has been published. Additionally, no information on secretory tissues of species belonging to the Catasetum cristatum alliance is available. Based on these arguments this present work aims to increase the knowledge on flower anatomy of Catasetum, giving details on the structures related to the resource production and the tissues involved in the fragrance secretion of selected species belonging to the " $C$. cristatum alliance".

Materials and methods. Ten species of the Catasetum cristatum alliance were analyzed (Tab. 1). The specimens were collected in natural areas from Brazil or bought from commercial orchids cultivators and maintained in the Orchidarium LBMBP of the Department of Biology, FFCLRP, São Paulo University, in the city of Ribeirão Preto (approx. $21^{\circ} 10^{\prime} \mathrm{S}, 47^{\circ} 48^{\prime} \mathrm{W}$; 546 m a.s.1.), state of São Paulo, southeastern Brazil. In some cases more than one individual of a same locality were potted with Pinus bark in a single pot. The vouchers material (living plants) was deposited at the orchidarium of the Molecular Biology and Plants Biosystematics Lab (Tab.1).

The morphological features of fresh flowers of Catasetum cristatum alliance were examined under a binocular stereomicroscope. To determine the osmophores location in each species, flowers were

TABLE 1. Species analyzed, locality (states of Brazil), flower sex (Male/Female), number of specimens analyzed (N) and reference number $(\mathrm{RN})$ at LBMBP Orchidarium.

\begin{tabular}{|c|c|c|c|c|}
\hline Species & Provenance & Flower sex & $\mathbf{N}$ & RN \\
\hline Catasetum arietinum Miranda \& Lacerda & PE & M & 1 & 844 \\
\hline Catasetum ariquemense Miranda \& Lacerda & RO & M & 1 & 924 \\
\hline Catasetum barbatum (Lindl.) Lindl. & AM & M & 1 & 952 \\
\hline Catasetum carolinianum Miranda \& Lacerda & GO & M & 1 & 946 \\
\hline Catasetum cristatum Lindl. & $\mathrm{co}^{*}$ & M & 1 & 990 \\
\hline Catasetum lanciferum Lindl. & MG & M & 3 & 943 \\
\hline Catasetum multifidum Miranda & PA & $\mathrm{M}$ and $\mathrm{F}$ & 2 & 815,818 \\
\hline Catasetum multifissum Senghas & RO & M & 1 & 916 \\
\hline Catasetum rivularium Barb.Rodr. & AM & M & 1 & 955 \\
\hline Catasetum semicirculatum Miranda & RO & M & 1 & 917 \\
\hline
\end{tabular}

* Commercial orchidary. 
collected during the fragrance production (2 to 5 days after flower opening in daylight period) from each specimen. The flowers were immersed in $0.1 \%$ (w/v) aqueous neutral red for 1-24 h (Vogel 1962). Additionally, they were longitudinally sectioned with a razor blade and immersed in a Lugol $1 \%$ solution for 1-10 min to localize tissue containing starch. The histochemical tests were made on transversal section of the labella stained with Sudan IV (Pearse 1985) to detect total lipids, and Lugol 1\% (Hinchman 1973) for starch grains. To characterize the anatomical structure, flowers of each species were fixed in formalin-acetic acidalcohol (FAA 50\%) for $24 \mathrm{~h}$ (Johansen 1940) and stored in $70 \%$ ethanol. The fixed material was dehydrated in ethanol series and embedded in Historesin (Leica). It was sectioned at a thickness of 10-12 $\mu \mathrm{m}$ using a rotary microtome. The sections were stained with Toluidine Blue (O’Brien et al. 1964). Observations were carried by using a light microscope Leica DM500. Images with a minimum of 600 dpi resolution were captured with a digital camera Leica ICC50 attached to the microscope. The terminology on morphology of secretory cells follows Koch et al. (2008).

Results. The flower morphology is similar among species of the Catasetum cristatum alliance. The male flowers are resupinate, and the sepals and petals are membranous, green and generally brown-spotted. Sepals are oblong-lanceolate, concave and with acute apex. The dorsal sepal is erect, while the lateral sepals are reflexed. Petals are oblong-lanceolate, convex, erect, and with an acute apex. The labellum is elongate, fleshy, with a saccate cavity in the middle portion, and with fimbriate margins (Figs. 1A-S). The adaxial surface of the labellum possesses two protuberances, named basal and apical calluses. The female flowers are nonresupinate and the sepals and petals are membranous, strongly reflexed, and entirely green. The labellum is galeiform, and very fleshy (Fig. 2). Protuberances are absent and the surface is longitudinally ribbed due the presence of prominent vascular bundles.

In all species analyzed, the secretory tissue occurs on the adaxial surface of the labellum of male and female flowers. The osmophore covers the entire surface of the labellum, extending to the margins of this structure, including the fimbriae (Figs. 3A-F). In male flowers, the secretory tissue is very evident on both calli. These protuberances are composed by a single tooth, three or numerous teeth. In some cases, the apical callus $(C$. barbatum and $C$. cristatum) or both calli (C. rivularium) split in a cluster of fimbriae. In C. multifidum and C. multifissum the apical portion of the labellum is tridentate and branched. In the rest of the labellum there is no evident ornamentation and the surface is smooth. In female flowers of $C$. multifidum, the secretory surface is smooth and the secretory tissue is homogeneously distributed.

The structure of the secretory tissue is similar among species belonging to the C. cristatum alliance. The osmophore has an epidermis and up to five subepidermal parenchymal layers. This structure is followed by vascular bundles, a non-secreting parenchyma and an abaxial epidermis (Fig. 4A). Variation in the epidermal cells morphology of male flowers was observed. In the majority of the studied species (i.e. C. arietinum, $C$. barbatum, C. cristatum, C. lanciferum, C. rivularium C. multifidum, and C. multifissum) the epidermal cells surface are tabular (flat) and anticlinal walls are tetragonal (on the calluses) to tetragonal-elongated (on the saccate portion) (Figs. 4B-C). In C. ariquemense the cells surface is papillous (on the calluses) to tabular with convex hunches (on the saccate portion) (Fig. 4D). In C. carolinianum the cells surface is papillous (on the calluses) to convex (on the saccate portion). Catasetum semicirculatum has cells with a convex surface (Fig. 4E). In female flowers of C. multifidum, the epidermis shows a surface with tabular cells, where its anticlinal walls are tetragonal (Figs. 4F). A thick cuticle covers the epidermis of both male and female flowers. This cuticle, because of his hydrophobic characteristic, seems to prevent the neutral red staining of osmophores from all species analyzed. The subepidermal parenchyma cells of both male and female flowers are anisodiametric and bigger than epidermal cells. The non-secreting parenchymal cells of female flowers have large intercellular spaces, contrasting to male flowers with more compact tissues.

The fimbriate margins of male flowers seem to be specialized structures for volatile emission, being composed almost entirelly by secretory cells. The epidermis are partially (C. arietinum, $C$. barbatum, $C$. multifidum, C. multifissum; Fig. 5A-B) or totally (C. cristatum, C. rivularium, C. semicirculatum) composed by flat cells or entirely composed by papillous cells 

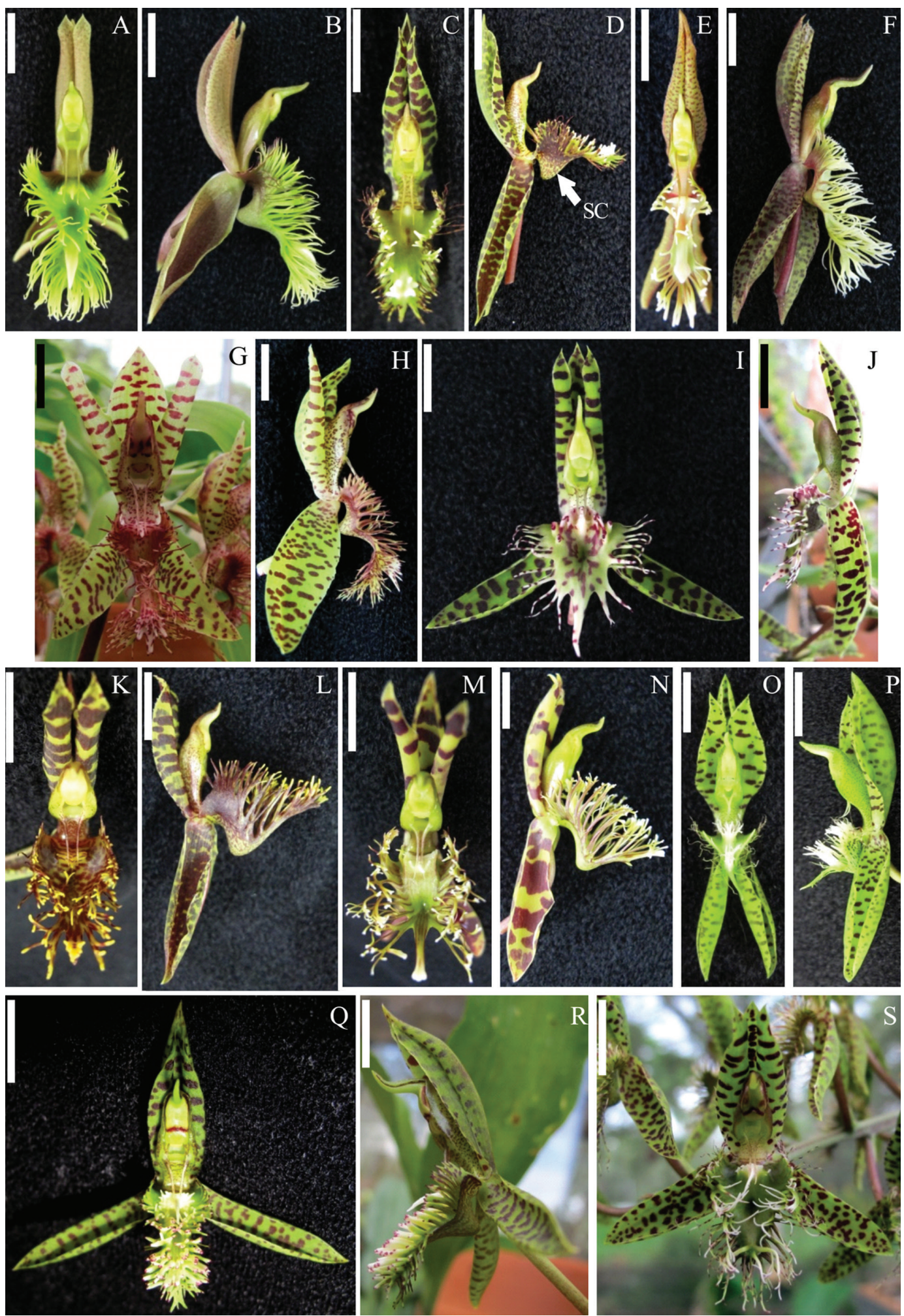
(C. ariquemense, C. carolinianum, C. lanciferum; Fig. 5C). Internally, the fimbriae possess thin vascular bundles (Fig. 5D).

In all species studied (male and female flowers) both epidermal and parenchymal cells of the secretory tissue are rich in oil droplets, which are stained with Sudan IV, confirming the lipophilic nature of the secretion in all the species analyzed (Figs. 6A-C). A large amount of starch grains is detected in the subepidermal parenchyma, but not in the epidermis (Figs. 6D). In the beginning of the scent production, the grains are aggregated and filled all the space inside the cells. After a few days those reserves are used, letting remain only small grains.

Discussion. Catasetum offer floral fragrances as a reward, attracting male euglossine bees as pollinators. In fact, its flowers are completely adapted to the euglossinophilous pollination syndrome. Their flowers possess big osmophores, where the chemical compounds produced inside the secretory cells volatize to attract male bees from long distances. To do that, the secretory tissue covers the entire adaxial surface of the labellum. Vogel (1990), describing the male flowers (labellum with galeiform morphology) of C. macrocarpum Rich. ex Kunth, C. fimbriatum (Morren) Lindl. and C. maculatum Kunth, clarified the anatomy and the nature of the resource produced. $\mathrm{He}$ described the labellar tissues according to its function in the following order: emission layer (adaxial epidermis), plasma-rich production layer (secretory parenchyma), horizon of veins (vascular bundles), parenchyma (not-secretory parenchyma) and outer epidermis (abaxial epidermis). Warford and Harrell (1996) only indicated the location of the osmophores in male and female flowers of C. pendulum Dodson using a neutral red staining method. The same osmophore pattern described by Vogel (1990) has already been documented for another euglossinophilous species, but not at the same size and complexity, continually covering plain and sacciform areas, calluses and fimbriae of the labellum. Only one Catasetinae (Cycnoches chlorochilon) and some genera of Stanhopeinae (Cirrhaea, Gongora,

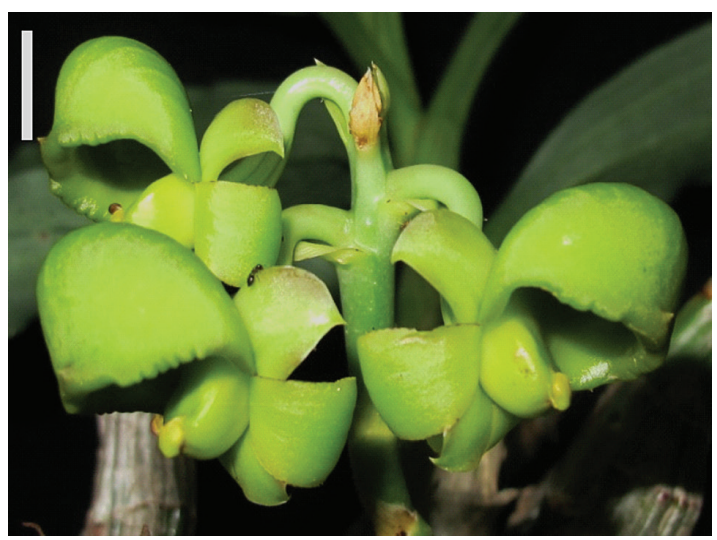

FIgURE 2. Female flower of Catasetum multifidum. Note that the female flowers are non-resupinate. Scale bar $=1 \mathrm{~cm}$.

Sievekingia and Stanhopea) have their osmophores pattern described in detail. Cycnoches chlorochilon has the most similar structure of the secretory tissue comparing with what we recorded in members of the $C$. cristatum alliance, but the secretory tissue is localized only in an egg-shaped cavity of the labellum (Anton et al. 2012). In Cirrhaea, the secretory tissue is localized in a midlobe protuberance, and extends to the basal portion of the inner side of the lateral lobes of the labellum (Pansarin et al. 2006, Pansarin et al. 2014). The flowers of Stanhopea and Gongora bufonia are very specialized, presenting a differentiated hypochile in the labellum, region where the secretory tissue is located (Stern et al. 1987, Curry et al. 1991, Pansarin \& Amaral 2009, Anton et al. 2012, Adachi et al. 2015). In Sievekingia, the labellum is less differentiated than Stanhopea and Gongora, presenting the osmophore in the base of a shallow pouch behind the callus (Curry et al. 1991). Grobya amherstiae and Cyrtopodium polyphyllum are closely related to Catasetum (e.g., Freudenstein et al. 2004), but belong to another pollination syndromes. $G$. amherstiae (Catasetinae) is pollinated by females of Paratetrapedia fervida Smith (Anthophoridae) bees that collect edible oil from the elaiophores (Pansarin et al. 2009). This species produce volatile compounds only to attract effective pollinators to the flowers, and its osmophore is epidermal and located on abaxial surface of the labellum. Cyrtopodium polyphyllum

Left, Figure 1. Diversity in male flowers of the Catasetum cristatum alliance. A - B. C. arietinum. C - D. C. ariquemense (note the saccate cavity - SC). E - F. C. lanciferum. G - H. C. carolinianum. I - J. C. semicirculatum. K - L. C. multifidum. M - N. C. multifissum. O - P. C. rivularium. Q - R. C. cristatum. S. C. barbatum. Scale bars: A - S = $1 \mathrm{~cm}$. 

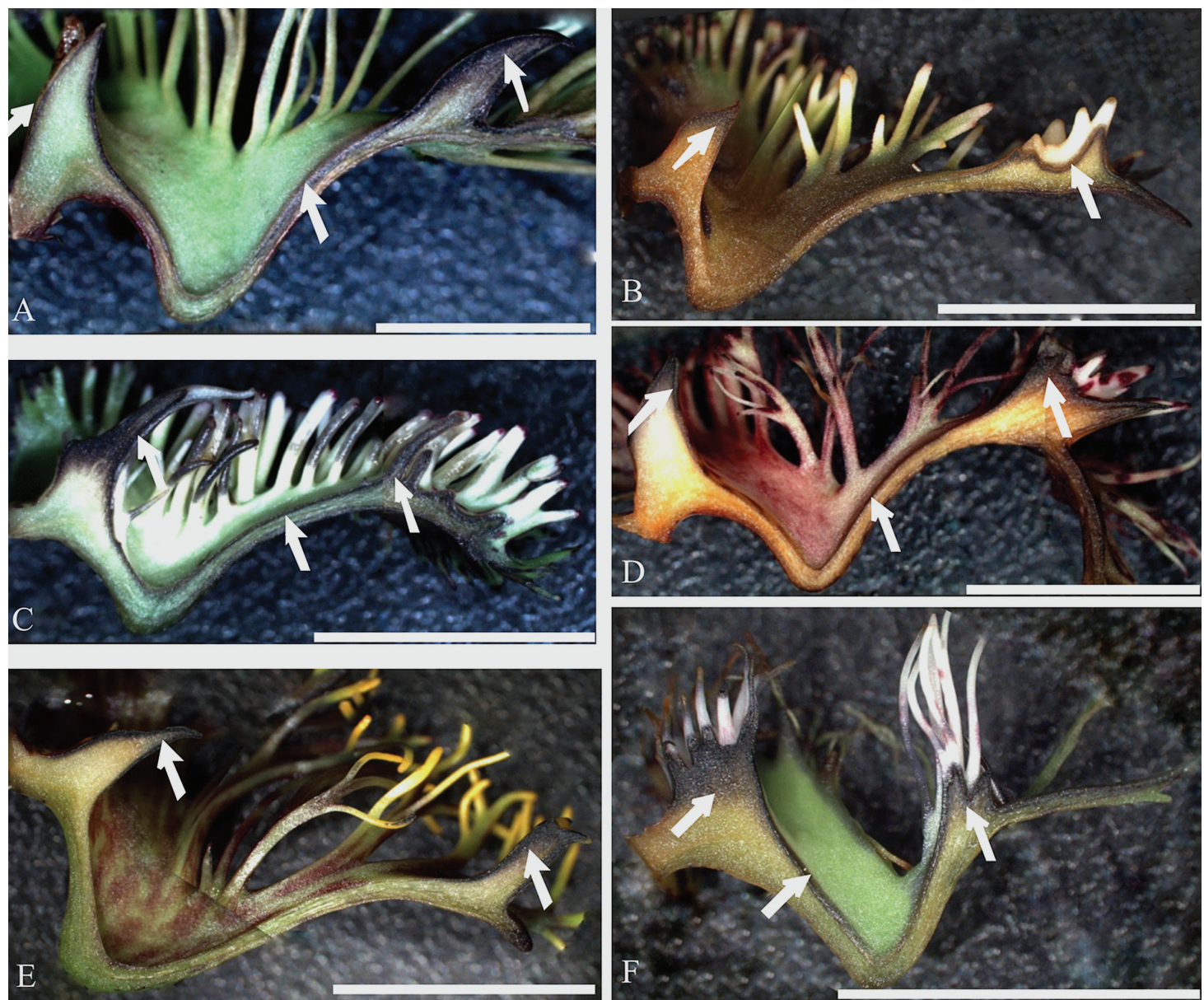

FigURE 3. Arrangement of the secretory tissue (based on tests with Lugol 1\%), in the labellum of male flowers of the Cata-

setum cristatum alliance. A. C. arietinum. B. C. ariquemense. C. C. cristatum. D. C. carolinianum. E. C. multifidum. F. C. rivularium. Note that in all species analyzed the secretory tissue is stained in black (arrows). Scale bars: A - F = $1 \mathrm{~cm}$.

(Cyrtopodiinae) is pollinated by deceit by Centridini bees and produce scent as attractant (Pansarin et al. 2008). The osmophores are multicellular protrusions, more evident on the callus of the labellum.

The species of $C$. cristatum alliance show some variation in epidermal cell morphology. The meaning of these modifications can have several explanations. Whitney et al. (2011), comparing flowers with flat and papillous cells, showed that presence of conical epidermal cells in petals enhance pollination success. This cells shape affect significantly flower colour, flower wettability and the tactile handling of the flower by pollinators. However, have limited effect on floral temperature and might have an indirect effect on scent dispersal. Interspecific variation in epidermal cells was reported on Stanhopea by Curry et al. (1991).
These variations have an evolutionary relevance, were the selective pressure seems to have favoured the development of more elaborate osmophores with papillae, rugae and trichomes. In Cirrhaea spp. the osmophores do not show interspecific variation in epidermal cells (Pansarin et al. 2014). All the seven species analyzed by these authors have epidermal osmophores with tabular cells covered by a thin cuticle. However, comparative or evolutionary studies of secretory structures in different species of the same genus are still very scarce. The subepidermal parenchymal cells of $C$. cristatum alliance seem to follow the same morphology and size pattern, corroborating with Stern et al. (1987). They observed that the morphology and ultrastructure of all cells within this region was essentially the same in Stanhopea wardii and S. oculata. 

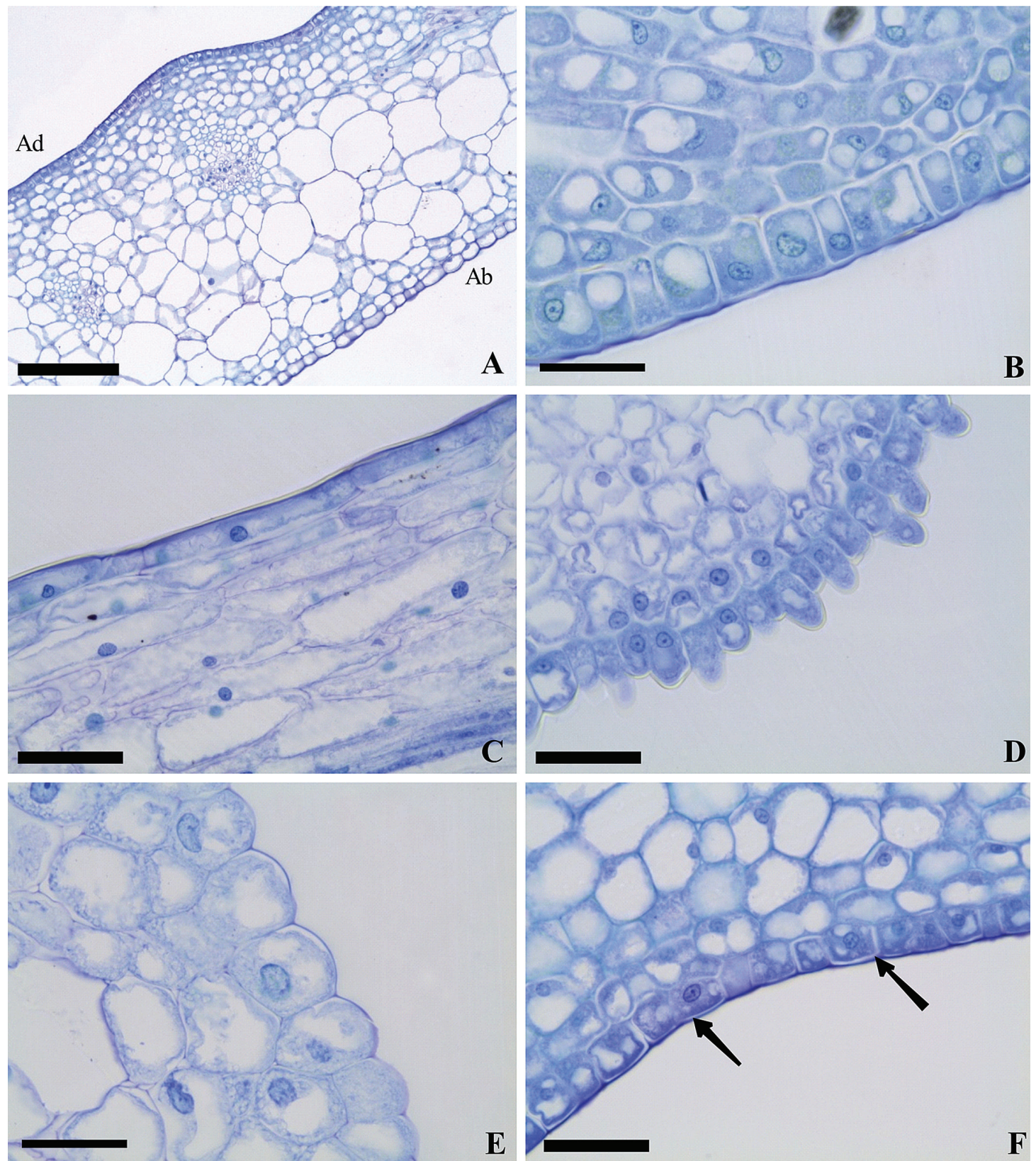

FIGURE 4. Labellum anatomy in the Catasetum cristatum alliance (stained with Toluidine blue). A. Transversal section of female flower labellum of C. multifidum; Note the secretory tissue of the adaxial surface (Ad), and the abaxial surface $(\mathrm{Ab})$, with a thin epidermis and the parenchymal cells with large intercellular spaces. B. Epidermis on the apical callus of male flowers of C. lanciferum. C. Epidermis on the saccate portion of male flowers of C. lanciferum. D. Epidermis on the basal callus of male flowers of $C$. ariquemense. E. Epidermis of the basal callus of male flowers of $C$. semicirculatum. F. Epidermis of female flowers of C. multifidum; Note the thick cuticle (arrows). Scale bars: A $=200 \mu \mathrm{m} ; \mathrm{B}-\mathrm{F}=50 \mu \mathrm{m}$.

The labellum morphology and anatomical features have an important function in pollination mechanism. The effectiveness of the pollination mechanism depends critically on the precision of pollinarium emplacement on the bee (e.g., van der Pijl \& Dodson 1966). To do that, the distribution of 

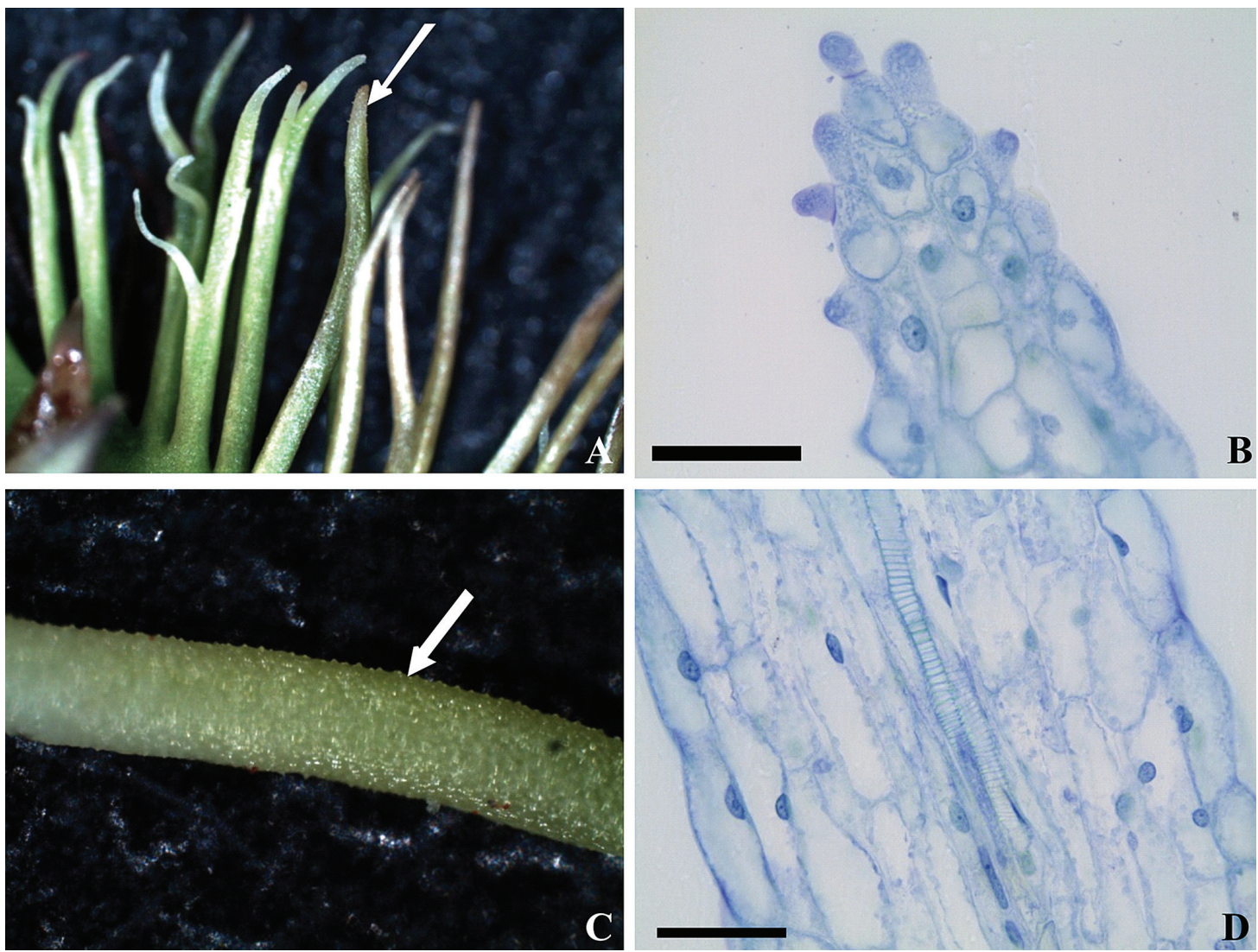

FIGURE 5. Fimbriae of male flowers of the Catasetum cristatum alliance. A. C. arietinum; Note the epidermis with papillous cells in the apex (arrow). B. Fimbriae apex of C. multifidum. C. C. lanciferum; Note the epidermis with papillous cells (arrow). D. Vascular bundle internally on the fimbriae of $C$. multifidum. Scale bars: B and D $=50 \mu \mathrm{m}$.

the secretory tissue must guide the bee below the column. According to Dodson (1962), there is a relation between the position of the antennae (the trigger of pollinarium ejection mechanism) and the secretory tissue. Dodson (1962), cited for Catasetum macroglossum: "the antennae are located just over the deepest point of the saccate labellum where the strongest odour is emitted". In addition, the thicker secretory tissue of basal callus in male flowers has the function to produce resource for collection, which results in a correct bee positioning below the column and allow the contact with the antennae. According to Vogel (1990), this resource does not stay available for a long time, and evaporate rapid. The fragrance produced in thinner secretory tissue, in the rest of lip areas, not seem to produce a collectible amount of resource. It probably have only attraction function for pollinators in these areas. The pollinia reception on the stigma is passive, and the secretory tissue distribution in female flowers stimulates the bee to enter in the galeiform labellum for resource collection. The pollinia is deposited on the stigmatic cleft of the column when the bee finish the collection and leaves the labellum interior (e.g., Dodson 1962). The female flowers have longer longevity (e.g., Milet-Pinheiro et al. 2015). However, we have not noticed any relevant modification in the secretory tissue of female flowers when compared to male flowers.

The C. cristatum alliance have the most complex lip morphology among Catasetum. The labellum is open and shows extraordinary structures, such as calluses and fimbriae. The three species analyzed by Vogel $(1963,1990)$ have more simple labellum morphology. However, both species (analyzed by him and us) show similar structure of the secretory tissue. Finally, 

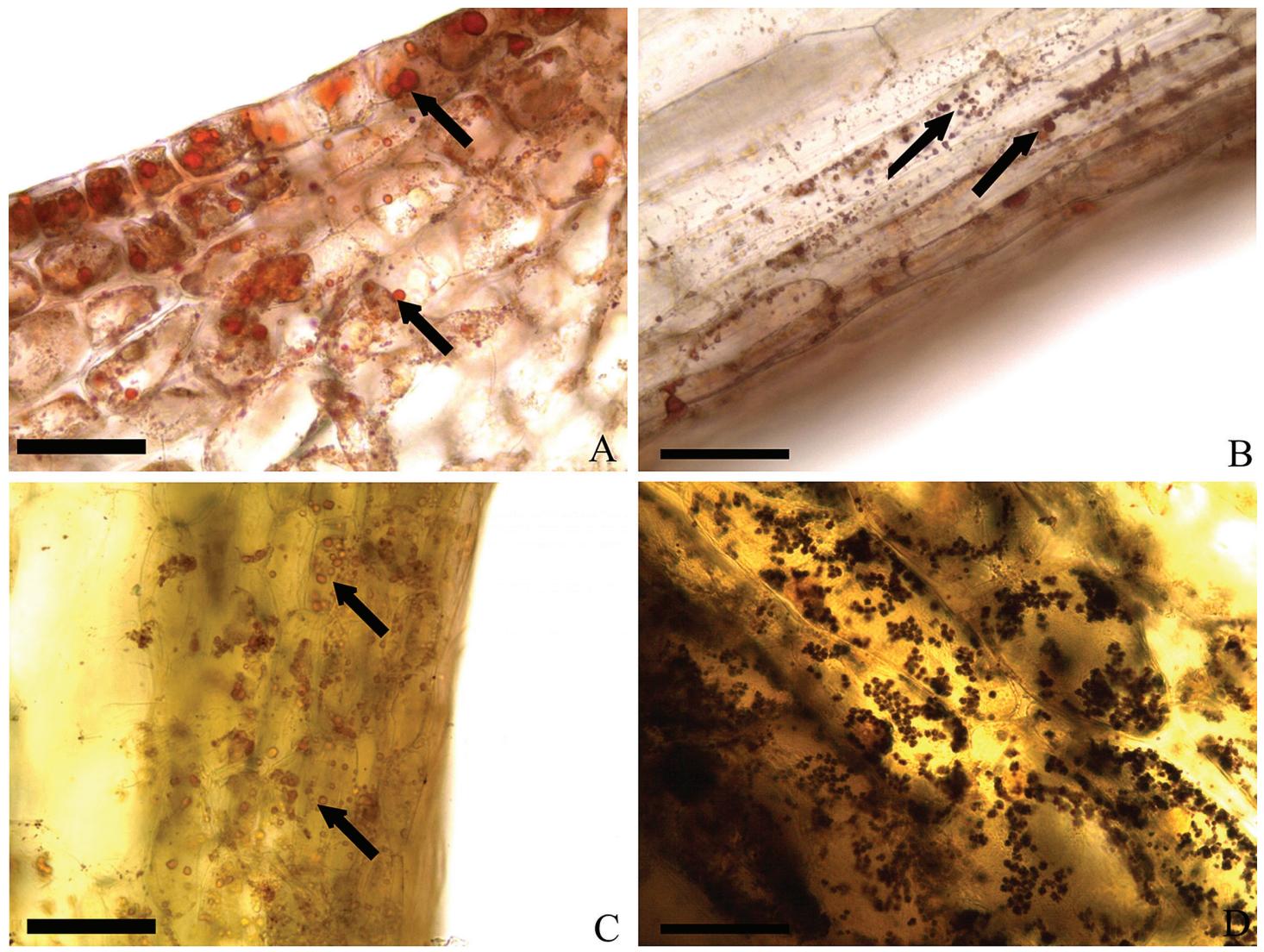

Figure 6. Histochemical tests on the labellum of male flowers of the Catasetum cristatum alliance. A. Lipids droplets in

C. rivularium callus (arrows) - stained with Sudan IV. B. Lipids droplets in C. carolinianum saccate portion (arrows) - stained with Sudan IV. C. Lipids droplets into a fimbriae of C. barbatum (arrows) - stained with Sudan IV. D. Starch grains in C. semicirculatum - stained with Lugol 1\%. Scale bars: A - D $=50 \mu \mathrm{m}$.

we were able to increase knowledge to the genus, highlighting the role of the osmophores in pollination mechanism. The characteristics described here can also be useful in the taxonomy of this neotropical and diverse orchid genus.

Acknowledgements. The authors thanks Silvia R. M. Pedro for help us with the slides preparation. This study is part of the $\mathrm{PhD}$ Thesis of EPF in the Post-graduation Program in Comparative Biology at the FFCLRP-USP. The first author received a scholarship from State of Amazonas Research Foundation (FAPEAM/SECTI/Governo do Estado do Amazonas). This research was supported by the State of São Paulo Research Foundation (FAPESP; Grant 2014/14969-6).

\section{LiTERATURE CITED}

Adachi, S. A., Machado, S. R. \& Guimarães, E. (2015). Structural and ultrastructural characterization of the floral lip in Gongora bufonia (Orchidaceae): understanding the slip-and-fall pollination machanism. Botany, 93, 759-768.

Anton, S., Kaminska, M. \& Stpiczynska, M. (2012). Comparative structure of the osmophores in the flower of Stanhopea graveolens Lindley and Cycnoches chlorochilon Klotzsch (Orchidaceae). Acta Agrobotanica, 65, 11-22.

Ascensão, L., Francisco, A., Cotrim, H. \& Pais, M. S. (2005). Comparative structure of the labellum in Ophrys fusca and O. lutea (Orchidaceae). American Journal of Botany, 92, 1059-1067.

Bicalho, H. D. \& Barros, F. (1988). On the taxonomy of Catasetum subsection Isoceras. Lindleyana, 3, 87-92.

Curry, K. J., Stern, W. L. \& Mcdowell, L. M. (1988). 
Osmophore development in Stanhopea anfracta and $S$. pulla (Orchidaceae). Lindleyana, 3, 212-220.

Curry, K. J. \& Stern, W. L. (1991). Osmophore development in Kegeliella houtteana (Stanhopeinae - Orchidaceae). American Journal of Botany, 78, 22-23.

Curry, K. J., Mcdowell, L. M., Judd, W. S. \& Stern, W. L. (1991). Osmophores, floral features, and systematics of Stanhopea (Orchidaceae). American Journal of Botany, 78, 610-623.

Dodson, C. H. (1962). Pollination and variation in the subtribe Catasetinae (Orchidaceae). Annals of the Missouri Botanical Garden, 49, 35-56.

Dressler, R. L. (1968). Pollination by euglossine bees. Evolution, 22, 202-210.

Dressler, R. L. (1993). Phylogeny and classification of the orchid family. Oregon, USA: Discords Press Portland.

Eltz, T., Whitten, W. M., Roubik, D. W. \& Linsenmair, K. E. (1999). Fragrance collection, storage, and accumulation by individual male orchid bees. Journal of Chemical Ecology, 25, 157-176.

Effmert, U., Buss, D., Rohrbeck, D. \& Piechulla, B. (2006). Localization of the synthesis and emission of scent compounds within the flower. In: Dudareva N, Pichersky E. (Eds.), Biology of floral scent (pp. 105124). Boca Raton, USA: CRC Press.

Fahn, A. (2000). Structure and function of secretory cells. Advances in Botanical Research, 31, 37-75.

Francisco, A. \& Ascensão, L. (2013). Structure of the osmophore and labellum micromorphology in the sexually deceptive orchids Ophrys bombyliflora e Ophrys tenthredinifera (Orchidaceae). International Journal of Plant Sciences, 174, 619-636.

Freudenstein, J. V., van den Berg, C., Goldman, D. H., Kores, P. J., Molvray, M. \& Chase, M. W. (2004). An expanded plastid DNA phylogeny of Orchidaceae and analyses of Jackknife branch support strategy. American Journal of Botany, 91, 149-157.

Gerlach, G. \& Schill, R. (1991). Composition of orchid scents attracting euglossine bees. Botanica Acta, 104, 379-391.

Gerlach, G. (2013). La pesadilla de Lindley - La biología sexual de Catasetum y Cycnoches. Lankesteriana, 13, 39-46.

Hills, H. G., Williams, N. H. \& Dodson, C. H. (1972). Floral fragrances and isolation machanisms in the genus Catasetum (Orchidaceae). Biotropica, 4, 61-76.

Hinchman, R. R. (1973). A permanent iodine stainmountant combination for starch in plant tissues. Stain Technology, 48, 344-346.

Johansen, D. A. (1940). Plant microtechnique. New York, USA: McGraw Hill.

Koch, K., Bhushan, B. \& Barthlott, W. (2008). Diversity of structure, morphology and wetting of plant surfaces. Soft Matter, 4, 1943-1963.
Kowalkowska, A. K., Kozieradzka-Kiskurno, M. \& Turzynski, S. (2015). Morphological, histological and ultrastructure features of osmophores and nectary of Bulbophyllum wendlandianum (Kraenzl.) Dammer (B. section Cirrhopetalum Lindl., Bulbophyllinae Schltr., Orchidaceae). Plant Systematics and Evolution, 301, 609-622.

Lacerda, K. G. (1998). Estudos em Catasetinae (Orchidaceae), complexo C. cristatum Lindl. - 1. Bradea, 8, 88-96.

de Melo, M. C., Borba, E. L. \& Paiva, E. A. S. (2010). Morphological and histological characterization of the osmophores and nectaries of four species of Acianthera (Orchidaceae: Pleurothallidinae). Plant Systematics and Evolution, 288, 141-151.

Milet-Pinheiro, P., Navarro, D. M. A. F., Dötterl, S., Carvalho, A. T., Pinto, C. E., Ayasse, M. \& Schlindwein, C. (2015). Pollination biology in the dioecious orchid Catasetum uncatum: How does floral scent influence the behaviour of pollinators? Phytochemistry, 116, 149-161.

Miranda, F. E. \& Lacerda, K. G. (1992). Estudos em Catasetinae (Orchidaceae) - 1. Bradea, 6, 45-60.

Nunes, E. L. P., Smidt, E. C., Stützel, T. \& Coan, A. I. (2014). What does floral anatomy and micromorphology tell us about Neotropical Bulbophyllum section Didactyle (Orchidaceae: Bulbophyllinae)? Botanical Journal of the Linnean Society, 175, 438-452.

Nunes, E. L. P., Smidt, E. C., Stützel, T. \& Coan, A. I. (2015). Comparative floral micromorphology and anatomy of species of Bulbophyllum section Napelli (Orchidaceae), a Neotropical section widely distributed in forest habitats. Botanical Journal of the Linnean Society, 177, 378-394.

O’Brien, T. P., Feder, N. \& McCully, M. E. (1964). Polychromatic staining of plant cell walls by toluidine blue O. Protoplasma, 59, 367-373.

Pansarin, E. R., Bittrich, V. \& Amaral, M. C. E. (2006). At daybreak - Reproductive biology and isolating mechanisms of Cirrhaea dependens (Orchidaceae). Plant Biology, 8, 494-502.

Pansarin, E. R. \& Amaral, M. C. E. (2009). Reproductive biology and pollination of southeastern Brazilian Stanhopea Frost ex Hook. (Orchidaceae). Flora, 204, 238-249.

Pansarin, E. R., Aguiar, J. M. R. B. V. \& Pansarin, L. M. (2014). Floral biology and histochemical analysis of Vanilla edwallii Hoehne (Orchidaceae: Vanilloideae): an orchid pollinated by Epicharis (Apidae: Centridini). Plant Species Biology, 29, 242-252.

Pansarin, L. M., Pansarin, E. R. \& Sazima, M. (2008). Reproductive biology of Cyrtopodium polyphyllum (Orchidaceae): a Cyrtopodiinae pollinated by deceit. Plant Biology, 10, 650-659. 
Pansarin, L. M., Castro, M. M. \& Sazima, M. (2009). Osmophore and elaiophores of Grobya amherstiae (Catasetinae, Orchidaceae) and their relation to pollination. Botanical Journal of the Linnean Society, 159, 408-415.

Pansarin, L. M., Pansarin, E. R. \& Sazima, M. (2014). Osmophore structure and phylogeny of Cirrhaea (Orchidaceae, Stanhopeinae). Botanical Journal of the Linnean Society, 176, 369-383.

Pearse, A. G. E. (1985). Histochemistry: theoretical and applied. 4th ed. Edinburgh: Churchill Livingstone.

van der Pijl, L. \& Dodson, C. H. (1966). Orchid flowers: Their pollination and evolution. Miami, USA: Coral Gables.

Pridgeon, A. M. \& Stern, W. L. (1983). Ultrastructure of osmophores in Restrepia (Orchidaceae). American Journal of Botany, 70, 1233-1243.

Pridgeon, A. M. \& Stern, W. L. (1985). Osmophores of Scaphosepalum (Orchidaceae). Botanical Gazette, 146, 115-123.

Romero, G. A. \& Nelson, C. E. (1986). Sexual Dimorphism in Catasetum Orchids: Forcible Pollen Emplacement and Male Flower Competition. Science, 232, 15381540.

Romero, G. A. (1992). Non-functional flowers in Catasetum orchids (Catasetinae, Orchidaceae). Botanical Journal of the Linnean Society, 109, 305-313.

Romero, G. A., Carnevali, G. \& Pridgeon, A. M. (2009). Catasetinae. In: A. M. Pridgeon, P. J. Cribb, M. W. Chase \& F. N. Rasmussen (Eds.), Genera Orchidacearum, Epidendroideae - Part II, Volume 5 (pp. 13-18). New York: Oxford University Press.

Sanguinetti, A., Buzatto, C. R., Pedron, M., Davies, K. L., Ferreira, P. M. A., Maldonado, S. \& Singer, R. B. (2012). Floral features, pollination biology and breeding system of Chloraea membranacea Lindl. (Orchidaceae:
Chloraeinae). Annals of Botany, 110, 1607-1621.

Stern, W. L., Curry, K. J. \& Pridgeon, A. M. (1987). Osmophores of Stanhopea (Orchidaceae). American Journal of Botany, 74, 1323- 1331.

Stpiczynska, M. (1993). Anatomy and ultrastructure of osmophores of Cymbidium tracyanum Rolfe (Orchidaceae). Acta Societatis Botanicorum Poloniae, 62, 5-9.

Stpiczynska, M. (2001). Osmophores of the fragrant orchid Gymnadenia conopsea L. (Orchidaceae). Acta Societatis Botanicorum Poloniae, 70, 91-96.

Teixeira, S. P., Borba, E. L. \& Semir, J. (2004). Lip anatomy and its implications for the pollination mechanisms of Bulbophyllum species. Annals of Botany, 93, 499-505.

Vogel, S. (1962). Die Druftdrüsen der Orchideen. Akademie der Wissenschaften und der Literatur, Mainz, Abhandlung der Mathematisch - Naturwussenschaftliche Klasse, 10, 598-763.

Vogel, S. (1963). Das sexuelle Anlockungsprinzip der Catasetinen- und Stanhopeen-Blüten und die wahre Funktion ihres sogenannten Futtergewebes. Österreichische Botanische Zeitschrift, 100, 308-337.

Vogel, S. (1990). The role of scent glands in Pollination. New Delhi, India: Amerind Publishing Co.

Warford, N. M. \& Harrell, B. (1996). Pollination, osmophores, and gender expression of Catasetum pendulum. Orchid Digest, 60, 74-78.

Whitney, H. M., Bennett, K. M. V., Dorling, M., Sandbach, L., Prince, D., Chittka, L. \& Glover, B. J. (2011). Why so many petals have conical epidermal cells? Annals of Botany, 108: 609-616.

Wiemer, A. P., Moré, M., Benitez-Vieyra, S., Cocucci, A. A., Raguso, R. A. \& Sérsic, A. N. (2009). A simple floral fragrance and unusual osmophore structure in Cyclopogon elatus (Orchidaceae). Plant Biology, 11, 506-514. 
